\title{
BETWEEN STATISTICS, DEMOGRAPHY, AND MONOGRAPHIC RESEARCH: GH. RETEGAN (1916-1998), A(NOTHER) SOCIOLOGIST WITHOUT A SOCIOLOGY
}

\author{
CORINA DOBOȘ 1
}

\begin{abstract}
By exploring the professional trajectory of sociologist Gheorghe (George) Retegan (1916-1998), this article addresses the epistemological and personal reconfigurations of the field of social sciences in post-war Romania, highlighting the complex relations and professional rivalries in the field after the Second World War, and their consequences for social knowledge. My study explores Retegan's published and unpublished works, archival documents, and an interview that Z. Rostás conducted with Retegan in the 1990s. I analyse three research ventures relevant for understanding Retegan's professional trajectory and methodological choices: the 1948-1950 family budget research that Retegan coordinated at the Central Institute for Statistics; the 1957-1959 monographic research he coordinated at the Institute for Economic Research; and his "farewell" to sociology and specialization in demography beginning in the 1960s. My article documents Retegan's remarkable capacity to develop research by way of formulating new questions, methodologies, and techniques, on the basis of the main elements of empirical research he learned during his training in sociology under the supervision of Anton Golopenția. Retegan's contributions to the field of empirical social research suggest how a context that was generally unfavourable for the development of social sciences (1948-1965) could be used in a creative way for the study of the social world. Epistemologically, the survival and even innovation of empirical research under unfavourable ideological and political conditions made possible the rehabilitation of sociology as a discipline in the much more favourable context of the second half of the 1960s.
\end{abstract}

Keywords: living standards, fertility rates, social sciences, epistemology, communism 


\section{Introduction $^{2}$}

The professional trajectory of sociologist Gheorghe (George) Retegan (b. in Căianul Mic, July 14, 1916 - d. in Bucharest, 1998) aptly illustrates how the institutional, intellectual, and political challenges that social sciences faced during the communist regime in Romania resulted in important epistemological and personal reconfigurations of the field. The institutional and ideological pressure exerted by political actors, often against the background of professional and personal rivalries among researchers, influenced the way different social sciences were constituted, as well as their later dynamics. Specific knowledge also resulted from elements of personal biography; and the setup and trajectory of different disciplines were closely intertwined with the fates and personalities of their promotors. For example, research into the re-institutionalization of sociology in the 1960s revealed some of the epistemological consequences of the deep professional and personal rivalry behind it, especially in terms of the research topics and methods pursued in sociology (Bosomitu, 2017).

The case of Retegan allows a closer study of these dynamics, as he fortunately survived the obsessive decade, professionally as well. Together with other researchers, he went to prison following investigations in relation to the Pătrășcanu trial. Yet unlike Anton Golopenția (d. 1951), Retegan survived the four years spent in prison (1950-1954). After his release he returned to research, unlike Anton Rațiu, for example. Retegan's professional trajectory and his choice of methods and disciplines can clarify some aspects of the winding development of sociology in the years of "misery" (1948-1965) (Bosomitu, 2014: 334), during its "underground" period (Zamfir, 2005b: 55). This was the time when the discipline's institutional structures were dismantled by interrupting all sociological training and closing down the centres for sociological research (Bosomitu, 2014: 337; Zamfir, 2005b: 55). The period marked "the collective drama of the professional body of the discipline" (Bosomitu, 2012: 59), but also the gradual, controlled re-institutionalization of sociology beginning in 1962-1965 (Bosomitu, 2014: 340-343).

The period 1948-1965 is difficult to evaluate because two important aspects in the chronology of the discipline are debated: how profound was the rupture in 1948; and to what extent can the sociological method be separated from the theoretical and hermeneutical system in which it had been devised originally. Cătălin Zamfir proposed an innovative research hypothesis about

\footnotetext{
2 This study was supported by a grant of Ministry of Research and Innovation, CNCS - UEFISCDI, project number PN-III-P1-1.1-PD-2016-1720, within PNCDI III, project DEMOECRO (https://demohistory.wordpress.com/).
} 
this period, to allow moving past the evaluation of sociology after 1948 only in terms of continuity or rupture with the interwar sociology (Bosomitu, 2012: 62-63). Zamfir argued that "although sociology was excommunicated as a bourgeois science until the mid-1960s, it continued to function illegally already during the harsh 1950s," since

distinguished sociologists of the Bucharest School [of Sociology] survived the
wave of communist terror [...] under different guises, other than sociology,
continued sociological research, and this was the most important transmission
source of a solid culture of sociological research to the young generation. They
stimulated the interest of young [researchers] for sociology, training them
professionally, guiding them through the bibliography of the field, including
by borrowing them their own books. (Zamfir, 2005b: 56)

Zamfir's implicit distinction between sociology as a discipline (condemned ideologically and institutionally) and its research method allowed him to overcome the canonical perspective on the history of sociology according to which institutional dismantling meant its disappearance (Zamfir, 2005b: 56).

In this article I further develop this research hypothesis, asking if the strategy of perfecting empirical research to the detriment of theorizing, adopted in a political and ideological context unfavourable for the discipline as a whole, is also indicative of the methodological alternatives configured within the Bucharest School already before 1945. Sandu convincingly identified the different perspectives and orientations on monographic research existing within the Sociological School of Bucharest: the complete monography (promoted by Gusti), the abridged monography (monografia sumară, promoted by Golopenția), and the problemoriented monography (promoted by Henri Stahl) (Sandu, 2012: 8-9; Golopenția, 2002). A nuanced perspective on the discipline in the post-war period encourages a similar approach to the methodological options in sociology before 1945 .

Various research campaigns carried out before 1965, such as the analysis of family budgets from 1948-1950, at which Retegan took part, the territorial systematization research carried out in Hunedoara county in 1949-1950, at which Henri Stahl participated, or the monographic research coordinated by Retegan at the Economic Research Institute in 1957-1959, were reconsidered during sociology's ideological and epistemological "thaw" period of the 1960s as relevant examples of "concrete sociology." Examining this process of reappropriation reveals the semantic field of the set-up and delineation of this disputed discipline, at the same time marking its historicity (Murgescu, 1962; Bugnariu, 1964; Mănescu, 1966; Murgescu et al., 1966; Stahl and Matei, 1966; Grigorescu, 1966). 
This study analyses three moments relevant for understanding Retegan's professional trajectory and methodological choices, as well as the situation of sociology in the first two decades after the war: the 1948-1950 family budget research that Retegan coordinated at the Central Institute for Statistics (Institutul Central de Statistică, henceforth ICS); the 1957-1959 monographic research he coordinated at the Institute for Economic Research; and his "farewell" to sociology and specialization in demography beginning in the 1960s. My main sources are Retegan's published and unpublished works, archival documents, and a very valuable interview that Z. Rostás conducted with Retegan in the 1990s (Retegan, 2005).

\section{Specializing in sociology}

Born in Transylvania, Gheorghe (George) Retegan studied philosophy at the University of Bucharest, where he was admitted on a scholarship in 1938 (Retegan, 2005: 282). He graduated in 1942 (Costea, 2001: 386), one of the 20 students choosing "sociology as main subject for undergraduate diploma" (Retegan, 2005: 301). During the university years, he participated at several monographic research campaigns: the study of 60 Romanian villages (1938) and the research in Dâmbovnic (1939) (Retegan, 2005: 311-312). Gh. Retegan contributed to 4 of the 17 abridged village monographs resulting from the 60 villages research, and also to the chapter on shepherding in Dâmbovnic. These studies were published at the beginning of the 1940s (Retegan, 1942a; 1942b; 1942c; Retegan and Zinverliu, 1942; Bârlea and Retegan, 1943).

Retegan was close with Anton Golopenţia, whom he had already met during his high school years, in 1936 or 1937, when Golopenţia visited the village where Retegan was born, Căianul Mic, while he was coordinating students' research (Retegan, 2005: 277; Sandu, 2012: 8). Golopenţia strengthened Retegan's decision to pursue sociology in secondary education (Retegan, 2005: 278), was his professor for the sociology seminar at the University of Bucharest (Retegan, 2005: 300-301), and at his proposal Retegan was hired at ICS in 1941 (Costea, 2001: 386; Retegan, 2005: 32; Golopenția S., 2009: 11-12). ICS, led by the physician and demographer Sabin Manuilă (1894-1964), became an important institutional option for many members of the Bucharest School of Sociology after the Romanian Social Institute (Institutul Social Român) was reorganized and the Youth Social Service (Serviciul Social al Tineretului) was discontinued in 1939 (Trebici, 1999a: 28; Golopenția S., 2009: 10-11). At ICS, among other tasks Retegan also coordinated the publication of the institute's journal, Buletinul statistic [The Statistical Bulletin] (File 82, 1951: 9). 


\section{BETWEEN STATISTICS, DEMOGRAPHY, AND MONOGRAPHIC RESEARCH: GH. RETEGAN (1916-1998), A(NOTHER) SOCIOLOGIST WITHOUT A SOCIOLOGY}

Drafted in the artillery at the beginning of the Second World War, Retegan wrote his undergraduate diploma thesis on the front, about the living conditions and standard of living of the cleaning staff at ICS (Retegan, 2005: 287-288). Retegan defended it when he returned to Bucharest, in the second half of 1941. The thesis was well received by Golopenția, who recommended it for publication (Retegan, 2005: 288), but "The living conditions of the cleaning staff in a public institution in the capital" only appeared in print in 1945 (Retegan, 1945).

In the second half of 1941, Retegan also participated at the population and goods census carried out in Northern Bukovina and Bessarabia, Romanian territories ceased to the Soviet Union in June 1940 and recovered in the autumn of 1941 (Retegan, 2005: 288-289). In 1942-43, he took part in the ethnographic research campaign of Romanians living east of the Bug River (Golopenția A., 2006; Retegan, 2005: 390-401). Together with Anton Rațiu, he contributed to the actual organization of the campaign (Rațiu, 1994: 20). Five research teams were set up, with Retegan working alongside Ovidiu Bârlea, Traian Georgescu, and Eugen Seidel in the commune Constantinovca, Vosnesensk county (Rațiu, 1994: 23). After the research campaign was concluded in 1943, Retegan returned to Bucharest, and continued working at ICS after 1944 as well.

In 1947, Retegan earned his $\mathrm{PhD}$ in Philosophy magna cum laude (Costea, 2001: 386), with a dissertation on "The Situation of the Working Class in the Main Capitalist Countries in the Past Fifty Years" (Retegan, 2005: 251). He was then recommended by Lucrețiu Pătrășcanu for a scholarship in Paris, but he did not get it. The recommendation weighted heavily against him during Retegan's investigation in relation to the Pătrășcanu case (Betea, 2011: 151-152).

\section{Labour statistics and the analysis of living standards}

In the second half of 1947, ICS underwent important changes to its activity. Dr Sabin Manuilă, founder and director of ICS since it was established in 1936, was fired as head of the institute in the summer of 1947. In August 1947, Anton Golopenția was named "delegated general director" of ICS, a position he held until September 1948 (Golopenția S., 2009: 16). ICS was placed under the authority of the Ministerial Commission for economic recovery and monetary stabilization, whose president was Gheorghe Gh. Dej. The commission secretary, Miron Constantinescu, had supported Golopenția's naming as head of the institute. ICS was involved in evaluating the situation of statistics in Romania and drafted a plan to reorganize it, which was discussed in October 1947 at the ministerial conference for the reorganization of statistics. The decisions made 
then aimed to reorient Romanian statistics towards providing new data, essential for the elaboration and implementation of economic planning by the communist regime (Trebici, 1999b: 29; 1999c: 16).

The conference was organized at the request of the Higher Council for National Economy (Consiliul Superior al Economiei Naționale) and was presided by Gheorghe Gheorghiu Dej, at the time Minister for Industry and Commerce. In his opening speech, he emphasized the need for "a statistics connected to economic processes" (Consiliul Superior Economic, 1947: 6). The Central Statistical Commission, headed by Miron Constantinescu, analysed the organization of Romanian statistics, revealing the precarious state of industrial statistics (Consiliul Superior Economic, 1947: 31), financial and commercial statistics (Consiliul Superior Economic, 1947: 48), and social statistics, i.e., "the study of the working population" and the analysis "of the workforce as a whole" (Consiliul Superior Economic, 1947: 56). Indeed, another report dating from the same period showed that of the 727 employees of ICS, only 4 worked on social statistics (File 82, 1951: 14). During the conference, it was pointed out that in 1938-1939 ICS attempted to start accounting for the workforce and failed "because of the lack of personnel and resources" (Consiliul Superior Economic, 1947: 57). ICS was

to be tasked with resuming immediately the statistical research of labour issues and with thoroughly organizing the Department for Labour Statistics within its technical division for Social Statistics. (Consiliul Superior Economic, 1947: 57)

Labor statistics would cover the distribution and movement of the workforce, labour productivity, the training of skilled workers, work conditions, wages, and workers' living conditions (family income and expenses, family budget, the level and structure of family consumption, the family's health and social circumstances) (Consiliul Superior Economic, 1947: 58-59).

In the summer of 1948, ICS was placed under the authority of the State Commission for Planning (Comisia de Stat a Planificării), established in July 1948 (Cătănuș, 2012: 108-114; Trebici, 1999c: 12-13). The need to restructure the field of statistics and re-establish its priorities led to the configuration of new areas of statistical expertise, in which Retegan easily found his place. Beginning with 1948, he led the newly established department for labour statistics and was involved in carrying out a survey on the living conditions of the families of factory employees and employees of state institutions (File 90, 1948: 27).

The survey was conducted in 1948-1950 on over 8,000 families from rural and urban areas, from Bucharest, and from all the country's historical regions (Mănescu and Vasilescu, 1967: 41; File 90, 1948: 2). The results were 
not published, and information on how the survey was conducted is fragmented, coming from different reports and statistical data sent to the State Commission for Planning. Established in July 1948 (Cătănuș, 2012: 108-114), the commission had authority over ICS starting in the summer of 1948 (Trebici, 1999c: 1213). From this fragmented information, I will attempt to reconstruct the main characteristics of the research, focusing on the epistemological continuities with the surveys conducted before 1945 as well as on the methodological innovations implemented for the 1948-1950 survey.

Internationally, family budget surveys were a constant preoccupation of different specialized agencies of the United Nations (the International Labour Office, the Statistical Commission), which aimed to consolidate the research methodology and standardize results (Mănescu and Vasilescu, 1967: 37-38). In the interwar period, several recommendations were adopted regarding the recurrence of surveys, the selection of households, and the surveys' duration (Mănescu and Vasilescu, 1967: 37-38; International Labour Office, 1927). However, the most significant step towards the formalization and consolidation of survey methodology was made on the occasion of the Seventh International Conference of Labour Statisticians, when on October 7, 1949, a resolution was adopted on the methodology for the study of families' standards of living (Mănescu and Vasilescu, 1967: 38; International Labour Office, 1949: 49-54).

The Council for Mutual Economic Assistance (CMEA), established in 1949, also set up a working group on family budgets. It brought together specialists from several socialist countries, who sought to define a working methodology specific to socialist countries (Mănescu and Vasilescu, 1967: 39). The influence of post-war international research instruments on the 1948-1950 survey is a topic for future research, but it can be assumed that it was rather limited at the time, especially since the survey in Romania started before these main methodological innovations in the field of family budget research at the international level. This hypothesis is strengthened by the fact that between 1942 and 1956 Romania was not a member of the International Labour Organization, and that no representative from Romania was present at the International Conference of Labour Statisticians in October 1949 (International Labour Office, 1949: 69-76).

Therefore, identifying the epistemological roots of the 1948-1950 survey is a productive line of inquiry. Gheorghe Retegan and D. C. Georgescu participated at the elaboration of the research methodology under the coordination of Anton Golopenția (Trebici, 1999b: 39), interim director of ICS between August 1947 and September 1948 (Golopenția S., 2009: 16). In September 1948, Golopenția and D. C. Georgescu were removed from ICS, and the mathematician Gheorghe Mihoc became the institute's director until 1951 (Trebici, 1999c: 12; Trebici, 
1999c: 30, 38). Retegan continued to work at ICS until March 1950 (Costea, 2001: 386). The experience gained by D. C. Georgescu and Retegan before 1945 from the surveys of peasants' nutrition (Georgescu, 1936; 1940) and the surveys of employees' family budgets (Retegan, 1945) proved useful for the 1948-1950 survey.

\section{Before 1945...}

Standard of living surveys in interwar Romania had been conducted and adapted especially for the study of the peasantry, while the number or surveys addressing employees and city dwellers was low (Retegan, 1945; Dunăre, 1945). The most remarkable was the study of peasant family budgets in 1938, conducted as part of the investigation of 60 Romanian villages. The research covered 235 rural households, distributed throughout the country (Stănculescu and Ștefănescu, 1942). The survey coordinated by Retegan at ICS in spring 1941 was meant to be the first in a series of "studies of state functionaries at all levels, but especially the basis for establishing an Office for Social Surveys with the goal of expanding this kind of research to all the professional categories in the country" (Retegan, 1945: 99, emphasis mine). The Office, which was supposed to provide data "about the overall standard of living of social classes" (Retegan, 1945: 99), was never established, while the information about "the standard of living of urban families" (Retegan, 1945: 102) remained profoundly lacking.

"The study of the state of professional categories with the help of the overall standard of living through surveys" (Retegan, 1945: 101) had already become a reputable tradition in Europe, being practiced at an increasingly larger scale beginning in the second half of the 19th century in most industrialized countries. Originally, these surveys focused mostly on the investigation and presentation of the structure and dynamics of workers' family budgets, and the results were used to substantiate social reform measures. This type of research became more encompassing after 1920, when the study of the income and expenses of workers' households was integrated to the broader study of "families' overall standard of living" (Retegan, 1945: 101, emphasis in original). Retegan also adopted this broader perspective in the research conducted in spring 1941, which sought to present the objective, measurable indicators of standard of living within the framework of respondents' behaviour and aspirations. The research consisted of filling in a personal sheet for every worker and analysing the size and source of the overall family income according to the number of family members and the number of wage earners in the family (Retegan, 1945: 112-115). Retegan also analysed the structure and percentage of 
different types of expenses (food, housing, clothes, tobacco and matches, transport, health and hygiene, intellectual and moral necessities, cinema and entertainment, other) incurred by a family relative to its size (Retegan, 1945: 115-124). The emphasis was on food expenses (which accounted for over $60 \%$ of the income) and on determining "the characteristics of dietary habits" in the studied families by analysing the food items consumed in a household. This also allowed qualitative assessments of the nutritional value of food consumption (Retegan, 1945: 116-119). This research also examined the degree to which income matched expenses, which was influenced not just by income and family size, but also by the "level of personal household management," a direct result of the respondents' educational and cultural level (Retegan, 1945: 124125). Finally, the analysis included a reflection on the respondents' "process of adapting to urban life" (Retegan, 1945: 125-127). The organizational and methodological experience Retegan gained conducting this (small) survey of employees' families that belonged to the same socio-professional category proved important for the larger-scale research at which he participated at the end of the 1940s.

\section{8-1950: The survey of family living conditions}

The research conducted at ICS between 1948 and 1950 was launched on July 1, 1948 (File 90, 1948: 23). ${ }^{3}$ Compared to the surveys on nutrition and living conditions before 1945, this was carried out on a much larger scale. According to Retegan, the survey aimed to centralize data on:

a. the structure of family budgets (wages, revenues from [agricultural] holdings, other earnings, etc.);

b. earners (family members who earned wages, regardless of their nature) and the average number of earners per family;

c. wage distribution by area (rural / urban) and region;

d. the structure of family expenses, with a focus on the close relationship between revenue levels and type of expenses;

e. the standard of living according to family size and burden, taking the family with no children as a basis for comparison; and the standard of living of the four main professional groups analysed. (File 90, 1948: 26).

\footnotetext{
3 The survey was deterred in Bucharest, and in Iași, Timiș, and Hunedoara counties, where the preparations for the survey were not ready in due time (File 90, 1948: 23).
} 
The research was meant to obtain data of "great significance from the point of view of economic policy," such as a breakdown of the cost of living into its main components and an evaluation of the overall consumption of foodstuff and clothing (File 90, 1948: 26). Moreover, it collected important information on the health, housing conditions, education, etc., of the members of surveyed families (File 90, 1948: 26).

More than 8,000 families were studied (File 90, 1948: 25), from several professional categories (the majority factory employees), from both rural and urban areas. Respondents selected from all historical regions of the country were surveyed over a period of 14 months (File 90, 1948: 2, 30). ICS departments at the central and regional levels (external offices) were involved in the survey, as well as trade union organizations for different production branches, which facilitated the recruitment of respondents. Social councillors (îndrumători sociali) participated as well; these were employed by different factories and institutions and worked voluntarily outside working hours, advising 15-20 families each (Vasilescu et al., 1972: 2002).

Families participated at the investigation on a voluntary basis and were offered consumption vouchers as an incentive (File 90, 1948: 23). Those selected for the survey received a questionnaire ("the family book") which they had to fill in and mail monthly; the data was centralized and processed statistically (File 90, 1948: 23-25). Retegan had already identified this data collection method to be best suited for such an investigation since the May 1941 survey. However, because of the war circumstances, it could not be applied then (Retegan, 1945: 103). The 1948-1950 survey targeted several professional categories, from both rural and urban areas (File 90, 1948: 95-110). The majority were factory employees from urban areas: administrative staff, technical personnel in managerial positions, auxiliary technical personal, skilled, industrial, and unskilled workers (File 90, 1948: 2, 28, 29). The most difficult task was to obtain conclusive answers from industrial and unskilled workers. In their case, the difficulty was finding "a head of the family to keep the family book in good condition," which was much easier in the case of administrative staff families (File 90, 1948: 24). Consequently, the researchers had to adjust how they processed the responses obtained from different professional categories, so as not to over-represent some and under-represent others. For the statistical analysis of the answers, employees, regardless of their branch of activity and area of provenance, were classified in four "professional groups" (grupe profesionale): workers, technicians, state employees, and factory employees (File 90, 1948: 18).

The analysis of centralized data yielded the structure of income and expenses for the surveyed families, according to the professional group to which the head of the family belonged (File 90, 1948: 18, table II). A comparative 
analysis of the income of employees in the months of August and September showed an increase in money income by $2.1 \%$ for all families (more pronounced for the families of factory staff and less pronounced for those of state employees) and an "encouraging" (File 90, 1948: 19) increase in the share of income obtained from exercising one's profession (wages, benefits, overtime) compared to the income in kind (evaluated in money and obtained from individual farming, hunting, fishing) and to different accounting entries (recovered debts, credit purchases, loans) (File 90, 1948: 95).

Expenses registered for the months of August and September were compared across 11 categories (food, clothes, shoes, household, hygiene, medical expenses, education, personal expenses, transportation and travel, investments, accounting expenditures) and the four professional groups (File 90, 1948: 19, table III). Findings showed that food costs, although they remained the most important category of expenses, had dropped by $4.8 \%$ in September compared to the previous month, with the largest decrease registered by factory employees and the smallest by state employees. This decrease corresponded to an increase in other expenses, especially instruction and education, with a higher spending on books and newspapers (File 90, 1948: 20). Food costs represented the larger share of the expenses of the surveyed families' expenses (File 90, 1948: 20-21, table IV), regardless of income size or the professional group to which the head of the family belonged, as 'the share of food expenses for workers' families is very close to that of state and factory employees" (File 90, 1948: 21). The study also found that "at the same income level the same food is consumed almost in the same quantities, regardless of the group to which the head of the family belongs" (File 90, 1948: 21).

The quantitative and qualitative study of nutrition in relation to income size, professional group, area of origin, and number of family members was central to the 1948-1950 statistical analysis. This had been a well-defined research topic already in the 1930s, though mostly applied to the study of the rural population. The investigation of the nutrition of families participating at the survey conducted at the end of the 1940s through the analysis of calorie consumption in a family was unitary and standardized, "according to a standard established in relation to the work effort expended and the number of consumption units" (File 90, 1948: 26). The "unit of consumption" used in the 1948-1950 research was 1 for those over 12 years old, with correction coefficients for age, not the number of family members. These coefficients had been set by the League of Nations in 1935-1936 (File 90, 1948: 31), and their use permitted a standardized analysis of food consumption and nutritional needs by age and expended work effort (File 90, 1948: 31). 
In the research he conducted in 1938 on the population of 59 villages, Georgescu had used the "consumption unit" and adapted the age correction coefficients, an important contribution towards the use of statistics in the analysis of nutrition. ${ }^{4}$ This experience proved very useful for the living standards research in 1948-1950.5

The study conducted at the end of the 1940s used the nutritional standard established in 1929 by the commission of physiologists in Geneva (File 90, 1948: 31), as had other studies carried out in the interwar period. The caloric deficiencies observed in August 1948 varied in inverse proportion to income, and in the case of the caloric need at rest deficiencies were more pronounced for the income groups below 10,000 lei (File 90, 1948: 31, 34). The qualitative analysis of food consumed in August also showed that the share of animal protein consumption, proteins that were "the most important for the body's well-functioning and maintenance," was not satisfying, and that their shortage was in inverse ratio to the size of families' income (File 90, 1948: 32-33).

The quantitative (File 90, 1948: 35, table 1) and qualitative (File 90, 1948: 40, table 6; 37, table 3; 41, table 7, table 8; 42, table 9) analysis of nutrition relative to income in August 1948 showed the different caloric averages, nutritional components, and types of food consumed by different income groups, and in so doing operated a daring synthesis between Georgescu's and Retegan's research interests. However, Retegan's role in analysing the data obtained in 1949-1950 is ambiguous. Although an interpretation of the data exists, it was not signed by Retegan, neither did he take responsibility for it otherwise (File 90, 1948: 6275, 76-94).

The atmosphere at ICS was becoming increasingly tense: during investigations related to the "Pătrășcanu case," several employees of the institution, including Retegan, came under direct scrutiny. A "Summary report on the leadership and the current situation at the Central Statistical Institute" dating from January 1949 noted that "ICS is an institution that lent considerable support, through the statistical data it provided, to the Antonescu regime in preparing and maintaining a war of aggression against the USSR" (File 3, 1949: 2).

The same report described Retegan as "a notorious supporter of [Iuliu] Maniu, and trusted man of Manuilă and Golopenția. The trade union and the party organization [from ICS] consider him a sworn reactionary" (File 3, 1949: 5). Anton Raţiu and Nicolae Betea were the first arrested from ICS - as participants

\footnotetext{
${ }_{4}^{4}$ Georgescu published the results of the investigations made in 1938 on the nutrition of 265 peasant families coming from 59 villages of Romania (Georgescu, 1940: 5-6, 9-10).

${ }^{5}$ In both the investigation from 1938 and the one in 1948-1950 the same percent of $10 \%$ for food waste was used. This percentage was considered by Georgescu as being more useful than the one of 5\% proposed by the Belgian E. J. Bingwood in 1934 (Georgescu, 1940: 11; File 90, 1948: 31).
} 
at the research campaign conducted east of the Bug River but also close acquaintances of Pătrășcanu, and tied to Manuilă's flight and Pătrășcanu's supposed attempts to flee the country. After he was removed from ICS in September 1948, in January 1950 Golopenția was arrested in the Pătrășcanu investigation (Betea, 2011: 313). Tragically, he did not withstand the rough conditions in jail and the investigation, and died in the Jilava prison in September 1951 (Trebici, 1999b: 40). Retegan was also arrested in March 1950 and detained in Jilava, initially accused and investigated for "high treason," later for "plotting against the social order" (Costea, 2001: 386). He was tried in April 1954, acquitted, and immediately released from prison.

Although Retegan's professional career at ICS was interrupted, his contribution to the methodology of the 1948-1950 survey is beyond question. Documentation of the family budget survey conducted in July-September 1948 shows methodological progress from the research carried out by Retegan and Georgescu before 1945, the two who had most contributed at defining the methodology and aims of the survey. Some of these improvements were: expanding the analysis of living standards to more professional categories throughout the country, especially industrial wage-earners from urban areas; detailed analysis of income structure; highlighting the relationship between income level, the level and type of expenses, and professional group; quantitative and qualitative analysis of family nutrition, correlated with income level and professional group.

Family budget surveys were conducted in the following decades as well, with some important changes: the questionnaire was gradually simplified so that it could be filled in easier by the families surveyed but also to allow a more efficient processing of data. After 1950, the survey was also "limited to families of employees", and starting in 1952 a research campaign targeted peasant family budgets (Mănescu and Vasilescu, 1967: 41-42). ${ }^{6}$ In 1953, the task of carrying out family budget surveys for both employees and peasants was transferred to the regional statistical offices. The number of surveyed families, set at the national level at 2,200 families of employees and retired workers and 3,000 peasant families, was maintained at least until 1964 (Mănescu and Vasilescu, 1967: 42). When standard of living surveys was conducted in an epistemological framework explicitly defined as sociological after 1965, many of the methodological directions and innovations applied in the 1948-1950 survey were reintegrated (Mănescu, 1966: 7-24).

\footnotetext{
${ }^{6}$ For studies about surveys on the living standards in postwar Romania see Mărginean (2015b; 2017).
} 


\section{7-1959: The monographic research}

The second significant moment in Retegan's post-war career was his involvement in the socio-economic monographic research campaigns carried out in 1957-1959 at the Institute for Economic Research (Institutul de Cercetări Economice, henceforth ICE). The institute was established in 1953 and belonged to the Academy of the Romanian People's Republic (Institutul Naţional de Cercetări Economice, 2013: 13).

After his release from prison in July 1954 (Retegan, 1950), Retegan could not find work for almost two years. He could not return to his previous position, and, as he later explained, he had not wanted that either (Retegan, 2005: 398). Finally, Retegan was hired at the Research and Design Institute for Paper, Cellulose, and Reed in October 1955, where he worked until June 1957 (Costea, 2001: 386; Retegan, 2005: 405), when he was transferred to ICE. His transfer to the institute came unexpectedly, as monographic research was also moved to ICE, as Retegan recalled:

And he requested my transfer to the Academy. I believe two people talked about me at the Academy, [Mihai] Levente, who took over the leadership of the Central Office for Statistics [Direcția Centrală de Statistică, DCS], and [Mircea] Biji. And Levente no longer wanted to... I told you that [sociological] research teams were established at DCS, and Levente wanted nothing to do with them. He said "I do statistics, not sociology. The Academy - that's its business." And then he transferred us to the Institute for Economic Research. "Who should we name there?" And then Levente and Biji said "That one [Retegan]... He's better than the others." I was vetted! /he laughs/ It ended in the known failure. (Retegan, 2005: 405)

The "research teams established at DCS" Retegan was referring to were the teams that were conducting since 1954 the "monographic research of villages in People's Republic of Romania" (Biji and Barat, 1956: 6), at the reorganized Central Institute for Statistics (renamed in 1950 the Central Office for Statistics, Direcția Centrală de Statistică, hereafter DCS). DCS was led between 1951 and 1956 by Manea Mănescu (Berca et al., 2013: 305, 338). Primarily motivated by the need for statistical data on agriculture (Retegan, 2005: 348), Mănescu encouraged restarting the monographic research of villages, in the mid-1950s. After being abandoned at the end of the 1940s, monographic research was resumed at DCS in 1954-56 in the broader context of the ideological thaw following destalinization (Bosomitu, 2017: 56), so that "at a time when references to sociologists and especially those around Gusti were still not possible, sociological monographs were considered a model for describing the situation of some 
villages" (Rostás, 2012: 89). The coordinator of monographic research at DCS had been Eugen Barát, a specialist in agricultural statistics, who although had not taken part at the research of the Bucharest School, was familiar with its works (Retegan, 2005: 348-249).

The monographic research of villages had been ideologically redefined in the mid-1950s "on the basis of Marxist-Leninist knowledge" and cleared of the "reactionary, anti-scientific theories of D. Gusti and the so-called Romanian Sociological School" (Biji and Barat, 1956: 12). Adapted methodologically and thematically to capture the new sociocultural and economic realities of Romanian villages in the context of the construction of socialism, it continued to be practiced until 1956. In 1956, Mihai Levente (1915-1986) was named head of DCS, which he led until 1962 (Betea, 2011: 131-134). Levente had also been hired at DCS by Golopenția (Golopenția S., 2009: 11), participated at the research campaign east of the Bug River (Retegan, 2005: 392), and had also been investigated in the Pătrășcanu case (Betea, 2011: 240). He probably wanted to avoid the risk of being associated with "sociology" - a field which at that time was in a delicate situation - and therefore this type of research was transferred to ICE (Murgescu, 1962: 240). Retegan was brought over to conduct these studies. Retegan recalled the difficult situation at the time, when it was not allowed to mention "sociology" but only "monographic research. That was the directive!" (Retegan, 2005: 349).

Later, in the 1960s, in a more relaxed ideological context, more favourable to the discipline of sociology, the studies that had been described in 1957-1960 as monographic socio-economic research were re-defined as "concrete sociological research" (Grigorescu, 1966). That was also when a distinction was made between the 1957-1959 studies and other monographic research conducted at ICE previously, which focused either on industrial or agricultural production units (Murgescu, 1962: 240) or on "theme problems" (Murgescu, 1962: 243). While the previous monographs conducted at ICE addressed "reciprocally conditioned problems [...] within the same economic unit", or looked to "a certain specific problem [...] in the varying conditions of several enterprises" (Murgescu, 1962: 243), the 1957-1959 monographic research went" beyond the limits of a productive unit (an industrial of farming enterprise), and took into account the totality of social-economic changes characteristic of the people's life" (Murgescu, 1962: 244). Regardless of how it was defined at the time, the 1957-1959 monographic research was a significant moment in the process of rehabilitating sociology as a science in Communist Romania (Rostás, 2012: 89-91; Székedi, 2017: 39).

Not just Retegan, but also other members of Gusti's School, such as Henri Stahl and Octavian Neamțu, took part at the organization and implementation of the 1957-1959 research campaign (Rostás, 2012: 89; Retegan, 2005: 344-345). 
The campaign was substantial and earned increased visibility. In 1958, a government decree was issued about the monographic research activity carried out by ICE, which had become the coordinating institution for "the monographic research of economic and social realities in our country" (HCM 902, 1958: art.1). Following requests from ICE, the decree involved local authorities (the executive committees of popular councils) in carrying out monographic research campaigns in both villages and cities. Every year, during research campaigns, these local structures were required to provide for the research teams "one physician, one veterinarian, one agronomical engineer, one teacher, and one specialist in every field typical for the researched localities" (HCM 902, 1958: art. 4). Moreover, different research and education organizations at the local and central levels were asked to contribute to the monographic research campaigns.

One of the key issues of the monographic research campaign carried out by ICE in 1957-1959 was training the personnel involved (Retegan, 1958: 40). Retegan played a decisive role, organizing and coordinating special training workshops. In the summer of 1957, the training took place at the V. I. Lenin Planning Institute (now the Academy of Economic Studies), and in the summer of 1958 close to Bucharest, at the school of horticulture. The workshops lasted for a month and counted among the teachers Mihai Pop and Eugen Barát, but despite sustained efforts, Retegan did not succeed to involve neither Stahl nor Octavian Neamțu in these workshops (Retegan, 2005: 349). Among participants were researchers from higher education institutions in Bucharest but also local specialists (physicians, agronomists) who were trained for field research, as Retegan recalled:

They'd never done sociological research before in their lives, or this kind of research. And so, we took people teaching in higher education - lectors, assistants, those higher up wouldn't come, but lectors and assistants came and locals. I wanted to work with agronomists from there rather than bring them from here. Or the physician - I'd rather have the local physician than bring a physician from here. So, we were bringing them. We wrote to the county secretary for propaganda - or for whatever they were, I don't know and asked, and he sent them. And for this one month we had food and accommodation for free. And travelling costed nothing. (Retegan, 2005: 351)

At a time when there were no possibilities for sociological training, the ICE campaign had created the framework for imparting summary knowledge about monographic research and sociology. Teaching monographic research was also facilitated by the elaboration, in the wake of the 1957 research campaign, of a "Guide for monographic research," an actual research textbook to which Retegan contributed and which was used as teaching material during monographic research training workshops in 1958 (Bochiș et al., 1959: 75). 
In 1958, it seemed that the situation had settled, if not for sociology as a whole, at least for its research methods. At the end of 1959, however, monographic research at ICE in general and Retegan in particular came under direct attack abruptly, in an article published in the journal Lupta de clasă (Class struggle) (Bochiș et al., 1959). The article condemned the low quality of the monographic research conducted in 1957, because of

serious deficiencies in the study and interpretation of phenomena, due first of all to the mistaken, non- Marxist perspective underlying the way in which monographic research was designed and organized. (Bochiș et al., 1959: 75)

Retegan was explicitly accused of prompting researchers to "objectivism" in their approach to the topic, which was equated with "ideologically disarming [the researcher] - meaning, open ground for bourgeois ideology and distorting reality. The Marxist researcher can only do fieldwork armed with the historical materialist approach, the only scientific approach to society" (Bochiș et al., 1959: 78).

The reasons behind this attack, which led to the temporary discontinuation of monographic research in the form Retegan had conceived and applied it at ICE, have been laid out and explained either in a broader ideological and international context (Rostás, 2012: 90-91; Székedi, 2017: 140), or with reference to circumstantial factors, such as professional jealousies and rivalries or pursuing short-term interests (Retegan, 2005: 345-347, 351-356). Carrying out monographic research along the lines drawn by Retegan at ICE was further complicated by the relocation of Miron Constantinescu to the institute, a key player in the fate of social sciences in Romania during the communist period. After his "fall" from the top ranks of the Romanian Workers' Party and his replacement as Minister of Education in July 1957, Constantinescu was "relocated" as director of the National Economy Institute (July 16, 1957-June 1958) (Bosomitu, 2014: 268269), and showed interest in monographic research, which resulted in a series of personal animosities within and outside of ICE (Retegan, 2005: 345-348).

Beyond the general and circumstantial factors that favoured the initiation and then discontinuing of the studies coordinated by Retegan at ICE between 1957 and 1959 (Retegan, 2005: 354), a summary epistemological analysis of this research attempt can lead to a better understanding of the way in which interwar "monographic research" was reinterpreted at the end of the 1950s, with the fundamental input of Retegan. This analysis is brief and limited because of the sources available, namely several articles about the research published in specialized journals between 1957 and 1966. 


\section{Methodological developments of interwar monographic research}

In an article published in 1958, Retegan defined the main features of the new research carried out at ICE, pointing to the ways in which it differed from similar studies in the past (Retegan, 1958). From the legacy of monographic research conducted by the Bucharest School of Sociology, Retegan claimed that two elements "had remained relevant" in 1958: the direct study of reality by "complex monographic research teams" and providing training prior to the research campaign (Retegan, 1958: 37-38). Of the research techniques formalized during the campaigns of the Bucharest School, Retegan highlighted: direct observation, archival research, interviews, documentary movies, and "statistical methods" that unfortunately "had not received full attention" (Retegan, 1958: 38).

Retegan also mentioned an article published in 1953 by Denis Szabo, professor at the Catholic University in Louvain (Retegan, 1958: 33; Szabo, 1953). Szabo explained Gusti's monographic research with explicit references to Gusti's theoretical system of which the method was an integral part (Szabo, 1953: 660). In an appendix, the article reproduced "the program of Prof. Gusti's monographic studies," noting that this could be adapted for the study of urban societies (Szabo, 1953: 667-669), something which Retegan also emphasized (Retegan, 1958: 33). Moreover, Szabo's article showed the innovations brought by the Gusti School in "the field of sociological research," with a focus on "the Gusti School's input to contemporary sociology" (Retegan, 2005: 246) and the superiority of the Gustian research approach compared to those of "American, English, and French sociologists" (Retegan, 1958: 33). For Retegan, this appraisal from the part of a "university professor [Denis Szabo]" (Retegan, 2005: 246) meant "recognizing the international primacy of the qualities of the direct research methodology elaborated by the Bucharest School" (Retegan, 1958: 33).

The fact that in 1958 Retegan avoided explaining the Gustian system of structuring and interpreting data, insisting instead on the research methodology of the Bucharest School, can also be understood in the context of a more general strategy adopted at a time when sociology continued to be a problematic discipline. The Bucharest School was only evoked prudently and within an ideological framework considered safe (Rostás, 2012: 89-90; Murgescu, 1957). Probably seeking to protect the research from possible ideological attacks, Retegan focused on the "technical" aspects of monographic research (interdisciplinary teams and different methods of direct research), without the Gustian interpretative system which represented the theoretical framework of monographic research: 


\section{BETWEEN STATISTICS, DEMOGRAPHY, AND MONOGRAPHIC RESEARCH: \\ GH. RETEGAN (1916-1998), A(NOTHER) SOCIOLOGIST WITHOUT A SOCIOLOGY}

20 years have passed since the last large-scale research of the Bucharest School, during which the design and the technique of social investigation have been enriched, under new social circumstances, with an experience that allows direct research [...]. The start of the Romanian society on the path of socialist transformation made it necessary to renounce the sociological theory of the Bucharest School and replace it with a Marxist-Leninist approach, creating a new design and considerably improving the investigation technique. (Retegan, 1958: 33)

Retegan's precautions proved to have been in vain. The attack against monographic research stemmed from ideological considerations and mobilized ideological arguments, including the criticism of Retegan's choice of a "bourgeois sociologist" such as Szabo, deemed "no less than a bourgeois ideologue [who] appreciates his apologetic brothers, showing full interest in pseudoscientific methods" (Bochiș et al., 1959: 79).

Seen in a broader context however, Retegan's prudent remarks indicating the need for theoretical innovation in monographic research prove substantial. The way in which he related, decades later, to Gusti's and Golopenția's perspectives on the configuration of sociology as a discipline, and especially its role and value for society (Retegan, 2005: 249-250), reveals Retegan's preference for Golopenția's empirical research of particular topics with immediate utility over the ambitious project of total sociology conceived and promoted by Gusti.

\section{The regional focus of monographic research}

As Dumitru Sandu convincingly argued, "the regional component of the Bucharest School" (Sandu, 2012: 7), although seemingly marginal, had in fact become increasingly important methodologically and epistemologically as the "region" represented not just a framework for the selection of villages but also "a framework of analysis and interpretation" (Sandu, 2012: 10). The typological study of villages that Golopenția coordinated as part of the 60 villages campaign, which Retegan was very familiar with, is a relevant example for the regional orientation of interwar monographic research. The study involved abridged monographs for villages considered typical: a) plain villages; ${ }^{7}$ b) mountain villages; ${ }^{8}$ and c) hill villages of winemakers and fruit-growers

\footnotetext{
7 The villages Șepreuș, Jdioara, Perieți, Văleni, Stoeșești, Corcmaz, Chirileni, Slobozia Pruncului, whose abridged monographs were published in Golopentia and Georgescu, 1943.

8 The villages Mărul and Bârsești, whose abridged monographs were published in Golopenția and Georgescu, 1943.
} 
with additional occupations. ${ }^{9}$ Analysing the publications and activities of the Bucharest School, Dumitru Sandu highlighted the importance of the communityregional perspective in interwar monographic research, pointing to the opportunity to study the (dis)continuity of this regional perspective in the post-war period (Sandu, 2012: 12).

A study carried out in the second half of 1949 in Hunedoara county at the initiative of the Urbanism Department of the Ministry for Constructions (Mărginean, 2015a: 76-83) aimed to "revise the best methods of documentation necessary for regional systematization in the future" (Stahl and Matei, 1966: 283), and therefore had a strong regional orientation. In 1958, Retegan (implicitly) referred to this study as having a "pronounced monographic character," conducted by several research centres "of regional importance" (Retegan, 1958: 30). ${ }^{10}$ After 1965, Stahl described the same campaign as one of "concrete sociological research" (Stahl and Matei, 1966: 283). Regardless of how it was subsequently defined, the Hunedoara county study had been complex. It was coordinated by a central multidisciplinary group, comprising: three architects, two sociologists, one demographer, one geologist, one climatologist, one urban engineer, one architect specialized in urbanism and one in rural constructions, one economist, one agronomist, one zootechnician, one forestry engineer, one physician, one railway engineer, and one historian. Henri Stahl and ten other former members of monographic research teams took part in it (Stahl and Matei, 1966: 286).

The explicit regional approach was extremely challenging from a methodological point of view, as it entailed moving away from

the old sociological studies of this kind, which had been conducted previously in the country and were limited to studying a pilot-village and then extending [the research] comparatively to a nearby area, with the intention to investigate a limited area of territory at the most. This time, the issue raised was how to research an entire county in order to integrate the results into a state plan, in the context of building socialism (Stahl and Matei, 1966: 286).

The research campaign was carried out in a county that was very heterogenous not just from a geographical, but also a socio-economic point of view. The main challenge was "collecting documentation that could lead to basic solutions to all the issues raised by the territory, a starting point for all the studies and specialized designs necessary for a unitary resolution" (Stahl and Matei, 1966: 284). The documentation collected was synthetized in "116 final

\footnotetext{
${ }^{9}$ The villages Cârligele, Căianul-Mic, Mocodul, Vidra, Bucșoaia, Bogații, Târnava, whose abridged monographs were published in Golopenția and Georgescu, 1942a.

10 See also Mărginean, 2015a: 79-81.
} 
sketches, of which 105 on specific issues (13 for geography, 7 for industry, 13 for agriculture, 17 for zootechny, 8 for forestry, 6 for trade, 12 for demography, 15 for public health, 11 for thoroughfares and means of communication, 3 for settlements), 8 syntheses (about underdeveloped areas), and 3 conclusions" (Stahl and Matei, 1966: 292). In what concerns the usefulness of the research campaign for the Hunedoara county, the documentation collected was indeed used for the county systematization plan, "the first to be published in the post-war period, considered a methodological point of reference in the field of regional socioeconomic development" (Mărgineanu, 2015a: 80).

The Hunedoara county research prompted multiple methodological innovations, which allowed the formalization of a research method adapted to the needs of regional studies. Defining and standardizing these needs subsequently made possible the systematic research, "village by village," of a county in Dobrogea, and summary documentation on "given issues," such as the study of the Bistrița Valley in the context of the Bicaz dam construction (Stahl and Matei, 1966: 292). Without a doubt, several elements of this regional approach were taken over and developed in the 1957-1959 campaign, to which Stahl also contributed.

The monographic research campaign conducted at DCS in 1954-1956 had investigated 20 villages from different regions of the country (hill, plain, winemaking, fruit-growing, animal raising, and mixed regions). These villages were selected as representative for the area where they were located. In order to capture the post-war political, economic, and social transformations, some of the chosen villages had previously been studied during the 60 villages research campaign from 1938, whose results were published between 1941 and 1943 (Golopenția and Georgescu, 1941; 1942c; 1942b; 1943), and some of the villages were less researched. Of the 10 villages studied in 1954, 8 had also been studied by monographic research teams in 1938; of the 9 villages investigated in 1955, one village; and of the 8 villages studied in 1956, seven (see Appendix). The typological approach to the study of villages, inaugurated during the 1938 campaign, had therefore been used in 1954 as well. The monographic research conducted at ICE in 1957-1959, however, explicitly aimed for an innovative regional approach.

\section{From socio-economic area to microregion}

The regional approach of the ICE research campaign in which Retegan was involved moved from the study of "the socio-economic area" (1957) to that of "microregions" (1958-1959). Retegan's choice for a regional approach represents another argument for him moving beyond Gusti's theoretical and interpretative framework in monographic research. 
The studies conducted in the summer of 1957 focused on the "socioeconomic area" (Bochiș et al., 1959: 72; Grigorescu, 1966: 320). This was a group of villages considered homogeneous and typical from a socio-economic point of view, of which one was a pilot village and the others were nearby villages (Murgescu, 1962: 244). 8 such socio-economic areas were studied, comprising 52 villages and one industrial centre (Grigorescu, 1966: 320). Each area was named after the pilot village and the campaign resulted in 8 monographs (Bochiș et al., 1959: 72):

- Dorobanțu (Medgidia rayon, Constanța region), typical for a collectivized area;

- Micăsasa (Mediaș rayon, Stalin region), typical for an area under the influence of an industrial center;

- Mădărașul de Câmpie (Tg. Mureș rayon, Hungarian Autonomous Region), a representative centre for the growth of industrial crops;

- Sânmihaiu Român (Timișoara rayon, Timișoara region) and Dioșdi (Caracal rayon, Craiova region), both typical for the cultivation of crops;

- Oltenești (Huși rayon, Iași region), typical for a mixed area - grain and viticulture;

- Budești (Oltenița rayon, Bucharest region), peasant trade area under the influence of the Bucharest urban centre;

- Horodnicii (Rădăuți rayon, Suceava region), typical animal husbandry area.

As detailed in an article published by Costin Murgescu in 1962, the campaign was carried out by multidisciplinary monographic research teams comprising 96 researchers, who studied 8 groups of villages. The teams were composed of economists - 41.6\%; philosophers - 11.5\%; agricultural engineers $10.4 \%$; statisticians $-8.4 \%$; physicians $-8.4 \%$; professors $-8.3 \%$; veterinarians $7.2 \%$; others $-4.2 \%$. The composition of a complex research teams was decided based on the features of the settlement researched (Murgescu, 1962: 247). Although this study had been openly described as monographic and Murgescu's article was published in a more favourable context for sociology then the one in which the research itself took place, Murgescu did not refer to the researchers who conducted fieldwork as "sociologists," but by the specializations (economists, statisticians) under which several of the members of the Bucharest School had continued their research careers (Bosomitu, 2012: 62).

The research carried out in 1958-1959 focused on several localities, both rural and urban. 7 areas were studied, comprising 56 localities, including one urban locality and 3 industrial centres (Grigorescu, 1966: 320). The concept of "microregion" was chosen for the integrated research of these different types of localities. The concept had been circulated before, as one of the solutions for the optimal systematization of Hunedoara county (Mărginean, 2015a: 80). 
The ICE monographic research campaign built on the experience in Hunedoara and the "microregion" became an instrument to analyse the social and economic dynamics between rural and urban areas. The "microregion" was defined not from an administrative, but a socio-economic point of view, and it comprised localities that had in common certain features of the production process and which gravitated around a pivot-centre; their study could lead to general summary conclusions (Grigorescu, 1966: 320). The microregion was formed from "a group of villages [...] with homogenous morphological, demographic, economic, and social characteristics, both with regard to their structure and their functions" (Retegan, 1958: 41). The presence among them of an urban centre with which "the other settlements maintain complex relations" was mandatory (Retegan 1958: 41). The microregion was structured around an urban centre - a city or industrial centre. Studying the microregion also answered the need to include urban centres in monographic research, as "excluding cities from the field of social investigation was and remains an anomaly. Their existence demands investigation" (Retegan, 1958: 41-42). Directing monographic research towards the study of urban centres within the microregion presupposed not just the study of cities of microregional importance, but also that of cities "of regional or national importance" (Retegan, 1958: 42). In several cases, the microregions also included areas in the midst of industrialization (Murgescu, 1962: 244; Bochiș et al., 1959: 72). In August 1958, ICE studied three such microregions: T,icleni-Rovinari, with the localities Țicleni, Rovinari, and the surrounding villages; Reșița, comprising the Reșița Steelworks and several villages nearby; and Câmpia Turzii, which included the factory "Industria sârmei" and several villages with economic ties to the city (Bochiș et al., 1959: 73; Retegan, 2005: 323).

The research plan elaborated by Retegan for 1958 listed 9 main issues to be tackled in the study of microregions (Retegan, 1958: 42):

- the microregion's geographical conditions;

- the issues of population and labour force;

- production relations; social classes and groups;

- the industrial, agricultural, etc., processes;

- exchanges between city and village;

- the material, sanitary, and cultural standard of living;

- the social institutions of the people's democratic regime;

- forming the socialist social consciousness; its content and forms of manifestation;

- overall evaluation and perspectives for development.

An article published in the mid-1960s pointed out that the study of microregions in 1958-1959 also included aspects related to factories, labour force migration towards industrial centres, social changes due to the transformation of 
the professional structure of the population investigated, effects of socialist industrialization on agricultural areas, and the population's standard of living (Grigorescu, 1966: 320).

Data collected in the study of the three microregions mentioned above, partially published after 1965, confirms this broad research perspective (Murgescu et al., 1966: 41-44). For example, part of the results obtained could be used for a diachronic analysis of the social mobility of work collectives in the three industrial centres present in the microregions (Reșița Steelworks, the factory "Industria Sîrmei" from Câmpia Turzii, and the oil and coal enterprises in Țicleni-Rovinari). In particular, the study examined the move from one socioprofessional category to another, correlated with the length of the industry's functioning (Murgescu et al, 1966: 41-44). Moreover, based on data collected in the 1958-1959 campaign, two factory monographs were published in 1963 by the publishing house Editura Academiei RPR: The Reşiţa Works in the Years of Socialist Construction and Wire Rod Industry - Câmpia Turzii (Institutul Naţional de Cercetări Economice, 2013: 15).

The research campaign concluded abruptly in 1959, following the virulent attack in the article "For the Scientific Perspective in Monographic Research" (Bochiș et al., 1959) which targeted both monographic research and Retegan personally. However, the methodological and epistemological innovations, the data collected, and even the basic training in the technique of monographic research proved important as they found their place in the new ideological and institutional context of the 1960s, which led to the re-institutionalization of sociology in 1965. In this context, much more favourable to sociology, the studies were reconsidered as telling examples of "concrete sociology," adapted to the new socio-economic realities of 1950s Romania (Bugnariu, 1964). Although with a delay, the results of the 1958-1959 campaigns were finally published in 1963 and 1966. They became reference points for sociology as a discipline in the process of being re-institutionalized and redefined, adapted not just to ideological pressures, but especially to the new socio-economic realities of socialist construction.

The monographic campaign coordinated by Retegan at ICE between 1957 and 1959 also brought important methodological innovations, such as the regional research approach detailed above and the use and further elaboration of statistical methods in monographic research (Retegan, 1958: 43; Grigorescu, 1966: 320).

The abrupt end of the research in 1959 had important consequences for Retegan's professional career. It marked his "symbolic" departure from sociology, paradoxically in a context much more favourable to sociology than it had been after 1948 (Retegan, 2005: 359-362). Familiar with demography 
ever since the research conducted east of the Bug River in 1942-1943 (Retegan, 2005: 371), Retegan specialized relatively quickly in demography, and became, in a short time, one of the most reputable researchers in the field in Romania.

\section{The 1960s: Demography and parting with sociology}

Retegan's decision to specialize in demography beginning in the 1960s can illuminate how the career change strategies adopted by some of the former members of the Gusti School in the post-war period contributed to the development of various fields of social research under communism.

Demography, a discipline on the rise beginning in the interwar period, developed within the institutional infrastructure set up by Sabin Manuilă, first at the Ministry of Labour and Health and later at ICS, where demographic statistics became one of the best-performing branches of centralized statistics (Trebici, 1999c: 11). The discipline kept a low profile after Manuilă fled in 1947, and especially during the period of ideological and institutional pressure on the social sciences in 1948-1954. In the 1960s, demography was (re)configured, developing in close connection to the economic sciences both institutionally and epistemologically (Trebici, 1981; 1990; 1996; 2011: 102-103). Attempts to set up a central institution for the study of demographic phenomena and to formulate public measures meant to influence their evolution picked up speed after 1965 (Trebici, 1968). This happened in the context of the demographic challenges brought by industrialization, urbanization, and the collectivization of agriculture, which led to a marked decrease in fertility rates that seemed to threaten the workforce supply. More and more articles on demographic issues at the national and international levels were published in statistics and economics journals such as Revista de Statistică (The Journal of Statistics), Probleme economice (Economic Issues), or Consfătuiri statistice (Scientific Reunions of Statistics). In 1968, the decision was made to establish a central institution, and in 1970 the National Commission for Demography was set up, under the helm of the State Council (Soare, 2011).

For Retegan, who worked at ICE until 1965 (Costa, 2001: 386), demography represented a new chance to continue his professional career in the field of social research. He is responsible for several improvements to the statistical measuring of demographic dynamics and to methodology, but also for attempts to define demography epistemologically and as a discipline. 
Starting in 1961, Retegan published under the pseudonym of G. R. Serbu ${ }^{11}$ a series of articles analysing the demographic dynamics of the biggest cities in Romania, in which he showed that the population increase in these cities, both before and after 1948, was the result of massive migration from rural areas rather than an increase in urban birth-rate (SSerbu, 1961a; 1961b; 1962; Retegan, 1965).

Retegan was also the first to compute the evolution of fertility rates in the post-war period, by making use of the "gross reproduction rate" a synthetic index that measured the degree of population replacement in a generation (S.erbu, 1962: 45). He highlighted the marked decrease in fertility beginning in 1956 , which he claimed was mainly explained by the legalization of abortion on demand in 1957 and the popularization of contraceptive measures (SSerbu, 1962: $47,51)$, and he argued for the importance of studying birth-rates in Romania (Retegan, 1964). His fertility computations remained reference points not just during the communist period, but also after (Ghețău, 1997: 4-5). The 1962 study was considered "the most important moment that defined demography as a science in the post-Manuilă and post-Golopenția period" (Trebici, 1999c: 23), as Retegan succeeded to reconstruct "for the first time the marriage rate and fertility rate for a period of 60 years" (Trebici, 1999c: 23).

Retegan tried to improve the research methodology in demography (Retegan, 2005: 355-357) arguing for the need to collect new types of data at registry offices and during population censuses, and especially for supplementing them with demographic surveys (Șerbu, 1962: 46-47; Retegan, 1962: 700). The surveys would provide new information on the relationship "between economic and social factors and the decrease in fertility rates, on the one hand, and on the other hand the attitude of each social class towards population reproduction and the mechanism of propagating demographic behaviour from one social class to another" (S.erbu, 1962: 46-47). The series of demographic surveys conducted in the 1960s and 1970s shows that his pleas did not go unechoed (Pescaru, 1964; 1967; Trăistaru, 1968).

Retegan also strived to (re)define demography epistemologically and as a discipline in the second half of the 1960s, when the institutionalization of the discipline picked up simultaneously with the start of the pronatalist policy of Ceauşescu regime (Retegan, 1966a; 1966b). In several articles written at the time, Retegan went to considerable lengths to clarify the epistemological and methodological autonomy of demography and its relationship with other social sciences, especially sociology, the monopolizing attempts of which Retegan

11 The demographer Vasile Ghețău indicated that Retegan and Șerbu are one and the same person. (Ghețău, 1997: 8) 
contested (Retegan, 1966b). Retegan's attempt to define demography as a social science can be understood not just in relation to sociology, but also in the context of the early 1960s, when serious efforts were made to (re)orient demography as an analytical and multidisciplinary science. This set it apart from mere statistics and rendered it a true "population science," also preoccupied with studying the factors that influenced demographic phenomena (Trebici, 1999c: 24). He did not shy away from a veritable "plea for the independence of demography" (Retegan, 1966b: 104), openly maintaining "demography's right to independence, to autonomy, even though I was a sociologist before becoming (if you agree) a demographer" (Retegan, 1966b: 101). He described the epistemological relationship between the two disciplines as follows:

Two different situations are possible: a) Independence, but with important borrowings in terms of theory and empirical research from the part of both sciences. The scientific achievements of one are taken over by the other, and vice versa; b) Demography is integrated by sociology, in which case demography is considered a sub-branch of sociology. The first situation is normal. The second should be discussed and rejected based on arguments. (Retegan, 1966b: 101)

Even so, Retegan conceded that it was difficult to choose between the two disciplines:

It is difficult to study demography without knowledge of sociology-and knowing sociology means knowing the social reality; it is equally difficult doing sociology without knowledge of demography-and knowing demography also means understanding the social side of demographic phenomena and processes. (Retegan, 1966b: 104)

Retegan's attitude and his claim might seem surprising considering not just his experience and qualifications in the field of sociology, but also the emulation and effervescence surrounding the discipline in the second half of the 1960s, including the professional opportunities in this field. Retegan's option for demography at a time when sociology was being reconfigured institutionally becomes more intelligible when it is corroborated by Retegan's admission during the interview with Z. Rostás.

In the mid-1960s, there were two alternative projects for the reinstitutionalization of sociology, one configured around Tudor Bugnariu and Traian Herseni, the other around Miron Constantinescu (Bosomitu, 2012: 65-66; 2014: 340-342). In the autumn of 1965, Retegan was invited to collaborate in the former, and found it wholly inappropriate, both in terms of the institutional architecture proposed and in terms of the research program (Retegan, 2005: 
359-360). Retegan was not asked to participate in Miron Constantinescu's project, however, which was ultimately the successful one (Retegan, 2005: 360). He later admitted that personally he would not have wanted to be invited, because "I broke off with sociology. I still do it for myself, at home. I think about sociology and..." (Retegan, 2005: 360).

New professional challenges probably helped him make the decision: Retegan served as advisor at the National Council for Scientific Research (1966-1969) and the Governmental Commission for Economic and Technical Collaboration and Cooperation (1969-1971) (Costea, 2005: 386; Retegan, 2005: 363-366). In parallel, he continued his activity in the field of demographic research, in particular economic demography (Retegan, 1967). In May 1971, he became member of the National Commission for Demography, which had been established two months prior (File II.20: 251; Retegan, 2005: 363). ${ }^{12}$ He was part of its secretariat and starting in 1972 also of its research group for the movement and structure of the population (File II.20: 3 ).

In 1973-1974, Retegan was involved in organizing the UN World Population Conference held in Bucharest in 1974. The Romanian National Committee for the organization of the conference was set up in November 1973. It included political actors as well as specialists from the National Commission for Demography and other institutions, and its aim was to organize the World Population Conference in Bucharest (File IV.118: 32, 58). Its permanent secretariat included, since April 1974, a scientific group formed by Retegan and Vladimir Trebici (File IV.118: 115-117). Retegan was one of the 19 advisors in the Romanian delegation who participated at the World Population Conference (File 6237, 1974: 73-74), which took place on August 19-30, 1974. Between 1973 and 1976, Retegan also had a short university career, teaching at the Academy of Economic Studies and at the University of Bucharest (Costea, 2005: 386).

\section{Conclusions}

The main moments in Retegan's professional trajectory and the methodological developments of his most important studies, as outlined in this study, allow sketching several conclusions regarding the evolution of the Bucharest School in the post-war period. Retegan's trajectory after 1948 highlighted the complex relations and professional rivalries in the field of social sciences after the Second World War, and their consequences for social

12 The membership of the National Commission for Demography was approved in May 1971 (Decret 197, 1971). 
knowledge. In what follows, however, I will not focus on this aspect, but rather on how the case of Retegan invites reflection on the fate of social research in Romania in the first post-war decades.

Retegan proved a remarkable capacity to develop research by way of formulating new questions, methodologies, and techniques. He did so on the basis of the main elements of empirical research he learned during his training in sociology under the supervision of Golopenția (Retegan, 2005: 284). In each of the two main research campaigns he conducted after 1948 - at DCS in 1948-1950 and at ICE in 1957-1959 - Retegan built and improved on the experience of empirical research from before 1945, according to his own admission:

I think I am a Gustian, even if the theoretical or fundamental ideas don't fit, because methodologically I cannot be any other way. Of course, I am someone who pays much more attention to quantitative methods now than was the case back then. (Retegan, 2005: 307)

Retegan's capacity to develop empirical research methods at a time when sociology as a discipline had been marginalized, methods which could later be appropriated as sociological, is better explained in light of the interview he gave Z. Rostás. Referring to the legacy of the Gusti School, Retegan distinguished between sociology's hermeneutical system and the sociological research method:

In my opinion, as I told you, the system was not well-articulated, it did not have a framework. There was, from my point of view, this very strong theoretical framework. The other elements, even if they were not fully engaged, not so well-articulated into this framework, would have been so in time. A strong framework presupposes a singular, well elaborated doctrine.

- That is, unitary...

- Yes. This is why everyone could fit in the School: those on the left, on the right, on the centre, or without political attitude or behaviour. A School that has a strong framework only allows in those who are earnest followers of that theoretical framework.

- It had more of a methodological framework.

- That one was strong. (Retegan, 2005: 245)

Retegan also distinguished between a "material" (the result of empirical research) and a research that becomes a "study" when the data obtained was presented in the framework of a "unitary system" (Retegan, 2005: 245). This explicit distinction between the theoretical framework of sociology (the system) and the sociological research method was also formulated implicitly by Retegan in his 1958 article, when he invoked Szabo's piece without any reference to the 
Gustian system but instead insisted on the qualities of the research methodology of the Bucharest School. As mentioned previously, if in 1958 this distinction could be understood as part of a semantic strategy aiming to place the research within a seemingly secure ideological framework, Retegan's statements in the post-1989 interview suggest that the distinction between sociological system and the methodology of sociological research was not just a figure of speech.

The preference for the research methodology over the hermeneutical system can be explained not just from the perspective of the institutional and ideological limitations in the 1948-1959/1965 period, when sociology was marginalized, and the discipline's research and education infrastructure was dismantled. It was also the sign of a different perspective on research methodology and the social role of sociology, increasingly more prominent towards the end of the 1930s within the Bucharest School of Sociology (Sandu, 2012).

After the institutional infrastructure of sociology was dismantled in 1948, Retegan, like other members of the Gusti School, tried to adapt to the times, and oriented himself towards other specializations in the field of social research (Bosomitu, 2012: 62-63). He oscillated between statistics, monographic research, and demography, areas in which he could use his knowledge of empirical research.

Retegan's preference for empirical research is probably also what helped him achieve methodological innovations, creatively building on the interwar legacy. I have discussed these developments both in the case of the family budget survey from 1948-1950 (including more socio-professional groups) and in the case of the monographic research from 1957-1959 (regional approach and statistical methods). In what concerns his specialization in demography, Retegan pointed to the need to conduct demographic research in order to capture the changes in people's behaviour and values with consequences for reproductive behaviour at the time of intense socio-economic and political transformations.

Retegan's contributions in the field of empirical social research might have even benefited from this lack of system, suggesting how a context that was generally unfavourable for the development of social sciences (1948-1965) could be used in a creative way for the study of the social world. Epistemologically, the survival and even innovation of empirical research under unfavourable ideological and political conditions made possible the rehabilitation of sociology as a discipline in the much more favourable context of the second half of the 1960s. My study showed how the empirical social research conducted in this "age of misery" of Romanian sociology transmitted and improved upon research methods developed before 1945. Moreover, the focus on empirical research instead of theory become an important feature of Romanian sociology after 1965 
(Zamfir, 2005a: 12-13; Zamfir, 2005b: 67-70). The survival and relaunching of sociology around empirical research perfected in a period when theorizing about the social world, beyond the official and ideologically acceptable theories, was risky. The research that Retegan carried out between 1948 and 1959 also shows that sociology's "age of misery" can be rethought as a period of experimentation and methodological innovation in the field of empirical research of social realities, which could later be developed in a more favourable institutional context.

Conducting empirical research in the absence of an institutional infrastructure dedicated to sociology specifically (practically non-existent between 1948 and 1959) was possible in an institutional context marked by the socio-economic development plans of the communist regime. The success and efficiency of economic planning, industrialization, urbanization, territorial systematization, and the collectivization of agriculture fundamentally relied on quantitative and qualitative information provided by empirical research. This led to an increase in the number of sites from where data was obtained and aggregated. If "sociology" had become politically and ideologically unacceptable, the knowledge and techniques of empirical research acquired before 1945 proved very useful for economic planning and the socialist transformation of the economy.

The empirical research conducted in 1948-1959 discussed in this article were re-appropriated, beginning in the 1960s, as sociological research: the family budgets survey carried out at Central Statistical Institute in 19481950; the territorial systematization studies conducted in Hunedoara county by the Urbanism Department of the Ministry of Constructions in 1949-1950; the village monographic research campaign coordinated by the Central Statistical Office in 1954-1956; and the monographic research implemented by Retegan at the Institute for Economic Research in 1957-1959. These were all hosted by central or regional state institutions where sociological research was not one of their specific activities.

The research campaigns in which Retegan was involved show that the need for empirical data, essential for elaborating the socio-economic plans of the communist regime, led to the configuration of a loose network of actors producing empirical knowledge, which functioned as an informal context for training and transmitting the investigation skills needed for the empirical examination of social realities. This happened before the re-establishing, in the second half of the 1960s, of several research and higher education institutions explicitly for sociology, with the researchers affiliated with them recognized as "sociologists." 


\section{REFERENCES}

Bârlea, O., Reteganul, Gh. (1943). Perieți. Un sat de muncitori agricoli din Ialomița [Perieți. A village of rural workers from Ialomița]. In A. Golopenția and D.C. Georgescu, 60 de sate românești. Vol IV: Contribuții la tipologia satelor românești. Sate agricole, sate pastorale [60 Romanian villages. Vol. 4: Contributions to a typology of the Romanian villages - Agricultural and pastoral villages]. București: Institutul de Științe Sociale al României, pp. 26-43.

Biji, M., Barat, E. (1956). Metoda monografică în studiul satelor RPR [The monographic method in studying the RPR villages]. Revista de statistică [The Journal of Statistics], 4 (3): 5-25.

Berca, M., Guțescu, L., Bold, I., Băcescu, M. (2013). Oameni de seamă: Economiști [Famous people: Economists]. București: Ed. Mica Valahie.

Betea, L. (2011). Cazul Lucrețiu Pătrășcanu [The case of Lucrețiu Pătrășcanu], București: Curtea Veche.

Bochiș, I., Părăluță, M., Spiridon, V. (1959). Pentru orientarea științifică în cercetarea monografică [For a scientific perspective in monographic research]. Lupta de clasă, 39(11): 70-80.

Bosomitu, S. (2012). In the age of 'misery'. The Romanian sociology during the Communist regime (1948-1977). N.E.C. Ștefan Odobleja Program Yearbook 20112012: 45-82.

Bosomitu, Ș. (2014). Miron Constantinescu. O biografie [Miron Constantinescu. A biography]. București: Humanitas.

Bosomitu, Ș. (2017). Tudor Bugnariu şi un proiect eşuat de reinstituţionalizare a sociologiei în România comunistă [Tudor Bugnariu and a failed project to reinstitutionalize sociology in communist Romania]. Revista română de sociologie, 28 (1-2): 55-77.

Bugnariu, T. (1964). Școala sociologică de la București [The sociologic school of Bucharest]. Contemporanul: săptămânal politic, social, cultural, nr. 42 (940) / 16.10. 1964.

Cătănuş, D. (ed.) (2012). România, 1945-1989. Enciclopedia regimului comunist. Instituţii de partid, de stat, obşteşti şi cooperatiste [Romania, 1945-1989. The Encyclopedia of Communist Regime. Party, State, Community and Cooperative Institutions]. Bucureşti: Ed. INST.

Consiliul Superior Economic (1947). Conferința ministerială pentru reorganizarea statisticii din România, ținută în ziua de 18 octombrie 1947 [The ministerial conference for the reorganization of statistics in Romania, held on 18th of October 1947]. București: Editura Institutului Central de Statistică.

Costea, Ș. (ed.) (2001). Sociologi români. Mică enciclopedie [Little encyclopedia of Romanian sociologists]. București: Ed. Expert.

Dunăre, N.M. (1945). Condițiile de viață ale fiilor de țărani vânzători ambulanți în capitală [The living conditions of hucksters in Bucharest]. Analele Institutului Statistic al României, 2: 175-232. 


\footnotetext{
BETWEEN STATISTICS, DEMOGRAPHY, AND MONOGRAPHIC RESEARCH:

GH. RETEGAN (1916-1998), A(NOTHER) SOCIOLOGIST WITHOUT A SOCIOLOGY
}

Georgescu, D.C. (1936). Consideration sur l'alimentation de la population paysanne de la Roumanie. Arhiva pentru Știință și Reformă Socială, 13 (1): 180-210.

Ghețău, V. (1997). Evoluția fertilității în România de la transversal la longitudinal [Fertility Trends in Romania. From Period to Cohort Analysis]. Revista de Cercetări sociale, 1: 3-85.

Golopenția, A., Georgescu, D.C. (1941). 60 de sate românești. Vol. I: Populația [60 Romanian Villages. Vol. 1: Population]. București: Institutul de Științe Sociale al României.

Golopenția, A., Georgescu, D.C. (1942a). 60 de sate românești. Vol V: Contribuții la tipologia satelor românești. Sate cu ocupații anexe [60 Romanian villages. Vol.V: Contributions to a typology of the Romanian villages. Villages with supplementary occupations]. București: Institutul de Științe Sociale al României.

Golopenția, A., Georgescu, D.C. (1942b). 60 de sate românești. Vol. II: Situația economică [60 Romanian villages. Vol. II: The economic situation], București: Institutul de Științe Sociale al României.

Golopenția, A., Georgescu, D.C. (1943). 60 de sate românești. Vol IV: Contribuții la tipologia satelor românești. Sate agricole, sate pastorale [60 Romanian villages. Vol. 4: Contributions to a typology of the Romanian villages- Agricultural and pastoral villages]. București: Institutul de Științe Sociale al României.

Georgescu, D.C. (1940). L'alimentation de la population rurale en Roumanie. București, Editura ICS.

Golopenția, A. (2002). Monografia sumară a satului. Utilitatea monografiilor sumare [Abridged Monography of the village. The usefulness of abridged monographs]. In A. Golopenția, Opere complete. Vol.I: Sociologie [Complete works. Vol. 1: Sociology]. București: Ed. Enciclopedică, https://sas.unibuc.ro/anton-golopentia/(25/05/2018).

Golopenția, A. (2006). Lucrările de identificare a românilor de la Est de Bug - rezultate și perspective [The identification of the Romanian Settlements East of River Bug results and perspectives]. In Golopenția A., Românii de la est de Bug [Romanian Settlements East of River Bug], vol. 1. București: Editura Enciclopedică, https://sas.unibuc.ro/anton-golopentia (10/05/2018).

Golopenția, S. (2009). Viața noastră cea de toate zilele [Our daily life]. București: Ed. Curtea Veche.

Grigorescu, P. (1966). Concrete sociological investigations performed at the Institute of Economic Research. Romanian Journal of Sociology, IV-V: 319-321.

Institutul Naţional de Cercetări Economice (2013). Institutul de Economie Naţională. 60 de ani de cercetare ştiinţifică 1953-2013 [The National Institute of Economics: 60 years of scientific research] www.ien.ro/sites/default/.../IEN\%20-\%2060\%20de\%20 ani_tipo.pdf, (15/06/2018).

International Labour Office (1926). Studies and Reports. 12: The Third International Conference of Labour Statisticians, Geneva,

https://www.ilo.org/public/libdoc/ilo/ILO-SR/ILO-SR_N12_engl.pdf(12/05/18).

International Labour Office (1949). Methods of Familiy Living Study. Report prepared for the Seventh International Conference of Labour Statisticians, Geneva. https://www.ilo.org/public/libdoc/ilo/ILO-SR/ILO-SR_NS17_engl.pdf(12/05/18). 
Mănescu, M. (1966). Cercetarea sociologică a nivelului de trai a populației. Schema generală a sistemului sociologic de indicatori ai nivelului de trai al populației [Sociologic research of population's standards of living. The general scheme of the sociological indices of the standards of living]. In Institutul de Filozofie al Academiei RSR, Teorie și metodă în științele sociale. Vol. III: Economie. Drept. Statistică. Sociologie [Theory and method in social sciences. Vol III: Economics. Law. Statistics. Sociology]. București: Ed. Politică, pp. 7-24.

Mănescu, M., Vasilescu, M. (eds.) (1967). Statistica nivelului de trai al populației [The standards of living statistics]. București: Editura Didactică și Pedagogică.

Mărginean, M. (2015a). Ferestre spre Furnalul Roșu. Urbanism și cotidian în Hunedoara sii Călan (1945-1968) [Windows towards the Red Furnace. Urbanism and Daily Life in Hundedoara and Călan (1945-19680]. Iași: Polirom.

Mărginean, M. (2015b). Welfare statistics. Analysing the quality of life in the 1950s Romania. Studia Universitas Babeș-Bolyai. Historia, 60 (2): 29-50.

Mărginean, M. (2017). Politicile caloriei: standard de viață, alimentație și legături de familie în România la mijlocul sec. al XX-lea [Politics of the calories: living standards, nutrition and family networks in mid-century Romania]. In Anca Dohotariu (ed.), Familia în România, între social și politic. O incursiune diacronică pluridisciplinară. [The family in Romania between the social and the political. A diachronic and interdisciplinary perspective]. București: Editura Universității din București, pp. 161-190.

Murgescu, C. (1957). Cercetările monografice la sate în România (I \& II) [The rural monographic research in Romania], Contemporanul: săptămânal politic, social, cultural, nr. 533 (567) /9.08.1957 \& nr. 534 (568)/23.08.1957.

Murgescu, C. (1962). Field research work as conducted by the Economic Research Institute of the Academy of the Romanian People's Republic. Romanian Journal of Sociology, I: 239-247.

Murgescu, C., Grigorescu, C., Retegan, G., Trebici, V. (1966). Influențe ale procesului de industrializare asupra mobilității sociale - Pe exemplul României [The influence of industrialization over social mobility- the Romanian case]. In Institutul de Filozofie al Academiei RSR, Teorie și metodă în științele sociale. Vol. III: Economie. Drept. Statistică. Sociologie [Theory and method in social sciences. Vol. III: Economics. Law. Statistics. Sociology]. București: Ed. Politică, pp. 33-47.

Pescaru, A. (1964). Studiul fertilității populației feminine din industria confecțiilor [The study of the fertility of women from the textile industry]. In A 3-a consfătuire științifică de statistică (1963) [The $3^{\text {rd }}$ scientific reunion of statistics (1963)]. București: DCS, pp. 893-903.

Pescaru, A. (1967). Experimentarea unei fișe de anchetă asupra fertilității în mediul rural [Experimentation of the use of a questionnaire in a rural fertility survey]. In A 5-a consfătuire științifică de statistică (1965) [The 5th scientific reunion of statistics (1965)]. București: DCS, pp.1302-1306.

Rațiu, A. (1994). Românii de la Est de Bug: cercetări etno-sociologice și culegere de folclor [The Romanians East of River Bug: Ethnic and Sociological Studies]. București: Editura Fundației Culturale Române. 
Retegan, G., Zinverliu, Z. (1942). Mocodul, un sat de cultivatori de ceapă și de producători de pănură din Granița Năsăudului [Mocondul, a village of onion farmers and textile producers from Granița Năsăudului]. In A. Golopenția, D. C. Georgescu, 60 de sate românești. Vol V: Contribuții la tipologia satelor românești. Sate cu ocupații anexe [60 Romanian villages. Vol.V: Contributions to a typology of the Romanian villages. Villages with supplementary occupations]. București: Institutul de Științe Sociale al României, pp. 65-85.

Retegan, G. (1942a). Cârligele, un sat de podgoreni din Râmnicu-Sărat [Cârligele, a vineyard village from Râmnicu-Sărat]. In A. Golopenția, D.C. Georgescu, 60 de sate românești. Vol V: Contribuții la tipologia satelor românești. Sate cu ocupații anexe [60 Romanian villages. Vol.V: Contributions to a typology of the Romanian villages. Villages with supplementary occupations]. București: Institutul de Științe Sociale al României, pp. 1-21.

Retegan, G. (1942b). Căianul-Mic, un sat de voștinari și strângătoare de lână din Munții Someșului. In A. Golopenția, D.C. Georgescu, 60 de sate românești. Vol V: Contribuții la tipologia satelor românești. Sate cu ocupații anexe [60 Romanian villages. Vol.V: Contributions to a typology of the Romanian villages. Villages with supplementary occupations]. București: Institutul de Științe Sociale al României, pp. 22-64.

Reteganul, G. (1942c). Păstoritul în Dâmbovnic [Shepherding in Dâmbovnic]. In A. Golopenția, Mihai Pop, Dâmbovnicul. O plasă din sudul jud. Argeș [Dâmbovnic. A commune in the south of Argeș county]. București: Institutul de Științe Sociale al României, pp. 21- 32.

Retegan, G. (1945). Condiţiile de viaţă ale oamenilor de serviciu de la o instituţie publică din Capitală [1941] [The living conditions of the cleaning staff in a public institution in the capital, 1941]. Analele Institutului Statistic al României, 2: 99-174.

Retegan, George (1950). Fișa matricolă penală a lui George Retegan [G. Retegan's prison file] http://www.bibliotecarepresiunii.ro/Fise\%20matricole\%20penale\%20\%20detinuti\%20 politici/R/R\%2002.\%20Reb\%20-\%20Rorlich/Retegan\%20Gheorghe/ P1040412.JPG (20/06/2018).

Retegan, G. (1958). O fază nouă în cercetarea directă a realității socio-economice din România [A new stage in the direct research of socio-economic reality in Romania]. Probleme economice, 11 (2): 31-34.

Retegan, G. (1963). Rolul și importanța anchetelor în studiul evoluției și interdependenței fenomenelor demografice [The role and importance of surveys in the demographic research]. A 2-a consfătuire științifică de statistică (1962) [The $2^{\text {nd }}$ scientific reunion of statistics (1962)], București, DCS, pp. 699-706.

Retegan, George (1964). Natalitatea RPR în perspectivă [Birthrates in Romania in the future]. Revista de statistică ,13(10): 67-74.

Retegan, G. (1965). Evoluția populației urbane a României [The evolution of urban population in Romania]. Revista de statistică. 14(7): 54-67.

Retegan, G. (1966a). Noi direcții de cercetare în demografia românească [New research directions in Romanian demography]. Contemporanul: săptămânal politic, social, nr. 47(1050) / 25.11.1966.

Retegan, G. (1966b). Demografia, știință socială independentă [Demography: an independent social science]. Revista de statistică, 15(4): 100-104. 
Retegan, G. (1967). Creșterea populației și creșterea economică [Population growth and economic development]. Viața economică, nr. 5(45) /10.11.1967.

Retegan, G. (2005). La un moment dat eu m-am supărat foc [At a certain point I became really upset]. In Z. Rostás, Parcurs întrerupt [A Broken Path]. București: Paideia, pp. 235-405.

Rostás, Z. (2012). 0 istorie nefardată a reabilitării sociologiei românești [Rehabilitating Romanian Sociology - An Unembellished History]. Transilvania, nr. 11-12: 88-101.

Sandu, D. (2012). Gândirea regională în mișcarea gustiană de ridicare a satului [Regional thinking in the Gustian movement of lifting up villages], Transilvania, nr. 11-12: 6-13.

Soare, F.S. (2011). Comisia Națională de Demografie [National Commison of Demography]. In Florin S. Soare, Luciana Jinga (eds.), Politica pronatalistă a regimului Ceaușescu. Vol.2 [The pronatalist policy of Ceaușescu regime, Vol. 2]. Iași: Polirom, pp. 87-90.

Stahl, H.H., Matei, Ion I. (1966). O experiență de documentare sociologică în materia de sistematizări teritoriale [A practice of sociologic documentation in territorial systematization]. In Miron Constantinescu (ed.), Cercetări sociologice contemporane [Contemporary sociological research]. București: Ed. Științifică, pp. 283-296.

Stănculescu, P., Ștefănescu, C. (1942). Analiza economică a gospodăriilor (bugete țărănești) [The economic analysis of peasant households]. In A. Golopenția și dr. D.C. Georgescu, 60 de sate românești. Vol. II.: Situația economică [60 Romanian villages. Vol. II: The economic situation], București: Institutul de Științe Sociale al României, pp. 205-292.

Szabo, D. (1953). L'étude de la société urbaine. Synthèse de recherches. Bulletin De L'Institut De Recherches économiques Et Sociales, 19(7): 599-669.

Székedi, L. (2017). Discursul de reabilitare a sociologiei în revista „Korunk” (19571964) [The rehabilitation discourse of sociology in the Korunk journal (19571964)]. Revista română de sociologie, $28(1,2): 35-54$.

Șerbu, G.R. (1961a). Evoluția numerică a populației orașelor mari ale RPR, 1859-1959 [The numeric evolution of the large cities in RPR, 1859-1959]. Revista de statistică, 10(3): 37- 50 .

Șerbu, G.R. (1961b). Căile de creștere numerică a populației orașelor mari ale RPR [Ways of increasing the large cities' population in RPR]. Revista de statistică, 10(5): 26-34.

Șerbu, G.R. (1962). Evoluția fertilității populației feminine din R.P.R. în perioada 19001960 [Evolution of female fertility in RPR between 1900 and 1960]. Revista de statistică, 11(4): 43-58.

Trăistaru, E. (1968). Planificarea familiei-anchetă în municipiul Cluj [Family planningan inquiry conducted in Cluj town]. Revista de statistică, 17 (10): 66-71.

Trebici, V. (1968). Organizarea cercetării științifice în demografie [The organization of scientific research in demography]. Revista de Statistică, 17(7): 29-39.

Trebici, V. (1981). Dezvoltarea demografiei ca știință în România [The making of demographic science in Romania]. Viitorul social, 10(4): 651-666.

Trebici, V. (1990). Demografia românească (1975-1989) [The Romanian demography between 1975 and 1989]. Sociologie Românească, 1(1-2): 161-170.

Trebici, V. (1996). Istoria demografiei românești. Note [The history of the Romanian demography. Notes]. Revista de cercetări sociale, nr.2: 146-153. 


\author{
BETWEEN STATISTICS, DEMOGRAPHY, AND MONOGRAPHIC RESEARCH: \\ GH. RETEGAN (1916-1998), A(NOTHER) SOCIOLOGIST WITHOUT A SOCIOLOGY
}

Trebici, V. (1999a). Anton Golopenția. Statisticianul și demograful [Anton Golopenția. The statistician and demographer]. In A. Golopenția, Opere complete II. Statistică, demografie și geopolitică [Complete works. Vol. II: Statistics, demography and geopolitics]. București: Editura Enciclopedică, pp.9-31.

Trebici, V. (1999b). Întâlnirea cu Anton Golopenția. [Meeting Anton Golopenția]. In A. Golopenția, Opere complete II. Statistică, demografie și geopolitică [Complete works. Vol. II: Statistics, demography and geopolitics]. București: Editura Enciclopedică, pp.33-41.

Trebici, V. (1999c). 0 istorie impresionistă a demografiei românești [An impressionistic history of Romanian demography]. Sociologie Românească, 10 (1): 9-31.

Trebici, V. (2011). Însemnări din memorie (VI) [Memories (VI)]. Glasul Bucovinei, 18(3): 87 110.

Vasilescu, M., Muntean, S., Sută, T. (1972). Statistica nivelului de trai în perioada de după cel de-al Doilea Război Mondial [The standards of living statistics in the postwar era]. In A 7-a consfătuire științifică de statistică (1969) [The 7th scientific reunion of statistics (1969)]. București, DCS, pp.2001-2009.

Zamfir, C. (2005a). Ce a lăsat Dimitrie Gusti sociologiei postbelice? [Dimitrie Gusti's postwar heritage]. Sociologie Românească, 3 (2): 11-14.

Zamfir, C. (2005b). 9 ipoteze pentru o analiză sociologico-epistemologică a sociologiei românești în perioada comunistă: 1944-1989 [9 hypothesis for a sociologic and epistemological analysis of the Romanian Sociology between 1944-1989]. Sociologie românească, 3 (1): 53-71.

\title{
LIST OF DOCUMENTS
}

File 3 (1949). National Archives of Romania-Headquarters. Fund CC al PCR- Secția Organizatorică [Fund CC of RCP- Organizatoric Branch], file nr.3/1949.

File 90 (1948). National Archives of Romania-Headquarters. Fund Comitetul de Stat al Planificării [State Commission for Planning Fund], file br. 90/1948.

File 92 (1951). National Archives of Romania-Headquarters. Fund Comitetul de Stat al Planificării [State Commission for Planning Fund], file br. 92/1951.

File II.20. National Archives of Romania-Headquarters. Fond Personal Ștefan Milcu [STtefan Milcu Personal Fund], file II.20.

File II.18. National Archives of Romania-Headquarters. Fond Personal Ștefan Milcu [SStefan Milcu Personal Fund], file II.18.

File IV.118. National Archives of Romania-Headquarters. Fond Personal Ștefan Milcu [Stefan Milcu Personal Fund], file IV.118.

File 6237 (1974). Diplomatic Archives. Fund Problema ONU [UN Fund], file nr. 6237/1974.

Decret197(1971). Decretul Consiliului de Stat [Decree of State Council] nr. 197. Buletinul Oficial al RSR [Official Bulletin of RSR] nr. 65/ 29.05. 1971.

HCM 902 (1958). Hotărârea Consiliului de Miniștri nr. 902 privind organizarea cercetărilor monografice în RPR [Council of Ministers Decision nr. 902 regarding the organization of monographic research in RPR]. Colecția de hotărâri și dispoziții ale Consiliului de Ministri al RPR [Collection of decisions and dispositions of the Council of Ministers of RPR] nr. 28, pp. 239-240. 


\section{APPENDIX}

Map of monographic research conducted in rural areas in 1938 and 1954-58

(Murgescu, 1962: 245)

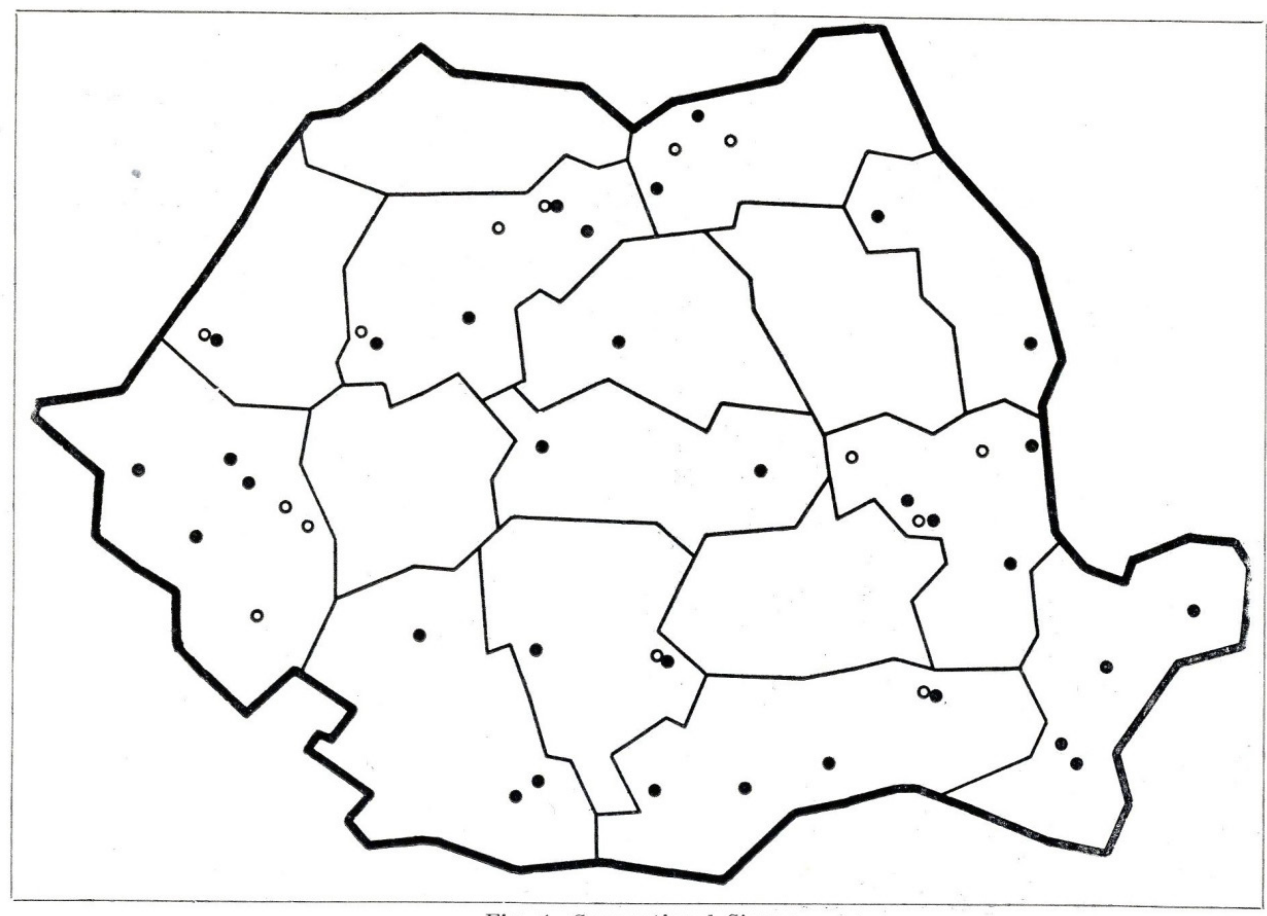

Fig. 1. Conventional Signs :

Villages investigated by the Rumanian Social Institule

O Areas investigated by the Central Statistics Agency and the Economic Research Institute. $N$. $B$. For 1938 only villages with published monographs have been indicated. In addition, economic condition was investigated in 17 villages
and population movement in 14 villages. 